\title{
Gate-to-gate life cycle assessment of biosurfactants and bioplasticizers production via biotechnological exploitation of fats and waste oils
}

Article

Accepted Version

Kopsahelis, A., Kourmentza, C., Zafiri, C. and Kornaros, M. (2018) Gate-to-gate life cycle assessment of biosurfactants and bioplasticizers production via biotechnological exploitation of fats and waste oils. Journal of Chemical Technology and Biotechnology, 93 (10). pp. 2833-2841. ISSN 0268-2575 doi: https://doi.org/10.1002/jctb.5633 Available at https://centaur.reading.ac.uk/75991/

It is advisable to refer to the publisher's version if you intend to cite from the work. See Guidance on citing.

To link to this article DOI: http://dx.doi.org/10.1002/jctb.5633

Publisher: Wiley

All outputs in CentAUR are protected by Intellectual Property Rights law, including copyright law. Copyright and IPR is retained by the creators or other copyright holders. Terms and conditions for use of this material are defined in the End User Agreement. 


\section{www.reading.ac.uk/centaur}

\section{CentAUR}

Central Archive at the University of Reading

Reading's research outputs online 
Gate-to-gate life cycle assessment (LCA) of biosurfactants and bioplasticizers

production via biotechnological exploitation of fats and waste oils

Short title: LCA of biosurfactants and bioplasticizers production from fats and waste oils

\author{
A. Kopsahelis ${ }^{1 \dagger}$, C. Kourmentza ${ }^{2 \dagger}$, C. Zafiri ${ }^{3}$ and M. Kornaros ${ }^{1 *}$ \\ ${ }^{1}$ Laboratory of Biochemical Engineering and Environmental Technology (LBEET), \\ Department of Chemical Engineering, University of Patras, 1 Karatheodori str., \\ University Campus, 26504 Patras, Greece \\ ${ }^{2}$ Department of Food and Nutritional Sciences, University of Reading, Whiteknights, PO \\ Box 226, Reading RG6 6AP, UK \\ ${ }^{3}$ Green Technologies Ltd, 5 Ellinos Stratiotou Str., 26223 Patras, Greece
}

\begin{abstract}
BACKGROUND: This study investigated the biotransformation of fats and waste oils towards glycolipid biosurfactants and bioplasticizers. The ecological performance and environmental impacts of the bioprocesses were evaluated aiming to assess their present environmental status and thus suggest future improvements using LCA methodology.

RESULTS: Biosurfactants, namely rhamnolipids and sophorolipids were obtained via fermentation. Bioplasticizers, Fatty Acid Ethyl Esters (FAEE) and Monoglycerides

${ }^{\dagger}$ These authors contributed equally to this work

* Corresponding author, email: kornaros@chemeng.upatras.gr, Tel.: +30 2610997418, Fax: +30 2610969584
\end{abstract}

This article has been accepted for publication and undergone full peer review but has not been through the copyediting, typesetting, pagination and proofreading process, which may lead to differences between this version and the Version of Record. Please cite this article as doi: $10.1002 /$ jctb.5633 
(MAG), were developed via enzymatic catalysis with selected enzymes in mesophilic temperatures via ethanolysis and glycerolysis, respectively. The study revealed that air emissions, electricity and thermal energy requirements are the key contributors to the potential environmental impacts in the LCIA. More specifically, rhamnolipids production has less energetic needs compared to sophorolipids manufacturing, resulting thus to lower environmental impacts. The increased thermal requirements of MAG production phase is the main contributor to their negative environmental performance, with the overall energy consumption for MAG production being 3-fold higher than the FAEE formation phase.

CONCLUSIONS: The assessment identified that among the biosurfactant production processes, the sophorolipids production resulted to $22.7 \%$ higher environmental impact compared to rhamnolipids. Similarly, FAEE production can be classified as a more environmental friendly process compared to MAG, resulting to $67 \%$ lower environmental impact based on the environmental indicators assessed.

Keywords: biosurfactants; bioplasticizers; rhamnolipids; sophorolipids; enzymatic catalysis; life cycle assesment 


\section{INTRODUCTION}

Our major source of energy derives from fossil fuels such as oil, coal and natural gas. However, as the world population continues to grow energy demands increase and the amount of fossil fuels is expected to fall short in the near future. In order to satisfy the ever-increasing demand of our modern society for energy, fuels and chemicals research has been focusing on the development of sustainable and innovative conversion processes based on biocatalysis of biodegradable feedstocks, such as waste streams and biomass ${ }^{1}$. Current policies and legislation promote the exploitation of such side-streams in order to make a successfull transition from petrochemical complexes to biorefineries that would have huge environmental and societal benefits ${ }^{2,3}$.

Bio-based chemicals and materials, produced by biocatalysts such as yeast, bacteria and fungi, present the advantages of being biodegradable, biocompatible and environmentally friendlier than their fossil fuel-derived counterparts. However, their production cost is still higher compared to the respective petrochemical ones, since process technologies are still researched, developed and optimized. Biotechnological production of biosurfactants is such an example. Several studies have demonstrated the potential of mostly hydrophobic organic residues, rich in fats, as raw materials towards the production of such high value-added compounds obtained by fermentation and enzymatic processes. Their triglycerides, consisting of fatty acids, can be used as precursors by several microorganisms or as initial reactants in lipasecatalyzed processes for biosurfactants' production ${ }^{4-6}$.

Microbial biosurfactants are amphiphilic molecules, comprised of both hydrophilic and hydrophobic moieties, that have the ability to reduce surface and interfacial 
tension. Several bacteria produce them as a key mechanism to facilitate hydrocarbon uptake through micelle solubilization or pseudosolubilization ${ }^{7,8}$. They are characterized by a wide variety of chemical structures including glycolipids, lipopeptides, polymeric polysaccharide protein complexes, fatty acids and phospholipids. Their main advantages against their synthetic counterparts are: their biodegradable nature, low toxicity, ecological acceptability, biological acivity as antifungal and antimicrobial compounds and sustainable production using renewable resources ${ }^{9,10}$. Based on those features, their applications are quite diverse including their use in food, pharmaceutical and cosmetic industries, bioremediation, toiletries and household cleanup ${ }^{5,10-14}$. Their global market by revenue is projected to reach $\$ 2,477.4$ Million by 2020 , compared to $\$ 1,870.1$ Million in 2013 , witnessing a compound annual growth rate (CAGR) of $4.1 \%^{15}$.

According to IUPAC (International Union of Pure and Applied Chemistry) a substance is defined as a plasticizer if when incorporated in a plastic material it enhances its flexibility, and processability due to its effect in reducing the second order transition temperature and the glass transition temperature $(\mathrm{Tg})^{16}$. Plasticizers are an important class of low molecular weight non-volatile compounds and are widely used in polymer industries as additives ${ }^{17}$. Plasticizers demand continues to grow along with the plastic industry. However, critical issues regarding the use of phthalates (the most dominant plastisizers used globally) and their migration have arrised including their human- and eco-toxicity. This is one of the main reasons why a lot of attention has been focused on research in order to gradually replace them, with natural-based plasticizers that are characterized by low toxicity, low migration and high biodegradability, offering 
competitive mechanical properties and produced in a cost-effective and sustainable manner ${ }^{18}$. It is worth noting that the bioplasticizers global market size is growing and is expected to reach up to $\$ 1,140.3$ Million by 2020 , characterized by a CAGR of $9.8 \%$ between $2015-2020^{19}$.

Monoacylglycerols and their derivatives are non-ionic emulsifiers widely used for the pharmaceutical and especially the food industry. They are also of great importance in synthetic organic chemistry where they are utilized as synthetic intermediates and plasticizers for various materials ${ }^{20,21}$. The synthesis of monoacylglycerols involves transesterification of triacylglycerols (TAGs) with glycerol at high temperatures and under nitrogen atmosphere employing inorganic alkaline catalysts ${ }^{22}$. However, several side-products are also obtained while low yields, low product quality and high-energy consumption are the major disadvantages of this conventional method. As an environmentally friendly alternative, enzymatic processes for monoacylglycerols synthesis based on lipase catalysis have been proposed. Those include, for example, selective glycerolysis/hydrolysis using regiospecific lipase enzymes, fatty acids esterification with glycerol and glycerolysis of fats/oils ${ }^{23,24}$.

Fatty acid ethyl esters (FAEE) are produced via esterification of fats/oils using ethanol as the catalyst, a process also known as ethanolysis. Usually an excess of alcohol is necessary to push the reaction to completion. In the literature several studies point out the potential value of FAEE as plasticizers in polyvinyl chloride (PVC) based applications ${ }^{25,26}$. FAEEs may derive from renewable, abundant and inexpensive raw materials and serve as alternatives to plasticizers such as phthalates.

So far, waste fats and oils have been mostly used for the production of animal feed, 
for soapmaking and the production of free fatty acids (FFAs) ${ }^{27}$. However, those byproducts may be used for the production of high value-added biotechnological products, in an effort to reduce their high production cost. To this end, waste fats and oils of different origin, were screened and utilized in lab- and pilot-scale for the fermentative production of biosurfactants and enzymatic production of bioplasticizers in the framework of the EU-funded project Bio-SURFEST (FP7-SME-2011, Grant no: 286834).

A critical tool in order to evaluate and understand the benefits and hotspots during production is life cycle assessment (LCA). This technique allows the assessment of several environmental impact categories associated with all or specific stages of the product's life. However, since most bioprocesses are still under development and optimization, with only a few products being produced at pilot or industrial case, LCA analyses are currently being performed ${ }^{28}$. In the case of biosurfactants only one study has been published recently, regarding the production of acetylated acidic sophorolipid biosurfactants and their application as a hand-washing detergent ${ }^{29}$. Regarding bioplasticizers, which could eventually substitute phthalates, several have reached commercial scale production. However, LCA assessments on their production are still limited ${ }^{30}$ or under investigation ${ }^{31}$.

The Bio-SURFEST project focused on the processes of biological production of glycolipid biosurfactants, in the form of rhamnolipids and sophorolipids, and also the enzymatic processes for production of FAEEs and MAGs. The ecological performance and environmental impacts of the production processes were estimated aiming to assess their present environmental status and thus enable future improvements by 
using the existing midpoint approaches of LCA methodology with impact categories such as global warming, ozone depletion, photochemical oxidation, acidification, eutrophication and non-renewable fossil usage. Midpoints are considered to be links in the cause-effect chain (environmental mechanism) of an impact category, prior to the endpoints, at which characterization factors or indicators can be derived to reflect the relative importance of emissions or extractions ${ }^{32}$. To compile the $\mathrm{LCl}$ of each bioproduct's manufacturing process, a series of process assumptions was made, the system boundaries for its production were determined and calculations were carried out based on the raw materials use and the electrical energy requirements. Biogenic emissions were also calculated for each process. In any case, the approach followed, and the results obtained from this study could be a useful tool for future studies on environmental performance of biosurfactants' and bioplasticizers' production.

\section{EXPERIMENTAL}

Life Cycle Assessment (LCA) methodology evaluates holistically the environmental consequences of a product system or activity, by quantifying inputs, in terms of materials and energy resources, and outputs such as emissions and wastes released to the environment assessing their environmental impacts. The environmental analysis developed in this work was carried out according to ISO 14040 guidelines and recommendations ${ }^{33}$.

For this LCA study, the complete life cycle inventory (LCI) of large-scale biosurfactant and bioplasticizers production is unavailable at the early design stage, which makes an LCA from gate-to-gate the most appropriate and practical approach 
for evaluating possible environmental impacts.

Gate-to-gate is a partial LCA looking at only one value-added process in the entire production chain. Since this calculation is a microscopic analysis, it is easily to identify a key unit ${ }^{33}$. Therefore, $\mathrm{LCl}$ information from this methodology can be used more directly in exploring engineering and chemistry changes to improve manufacturing processes which is the fundamental part in the assessment boundaries.

The detailed operating strategy under which the systems was assessed, has been optimized and validated under the frame of Bio-SURFEST project, and is currently confidential due to patent application. Further information on the process description can be found in the projects web site (http://www.biosurfest.com).

\section{Goal and scope}

The goal of this study was to establish an up-to-date Life Cycle Inventory dataset to access the potential environmental impacts of biosurfactants and bioplasticizers production. Moreover, the results of this gate-to-gate analysis consolidated with the environmental effect of the other production stages, could generate the full Life Cycle Assessment of the products after the development of the whole Life Cycle scenario from Cradle-to-Grave. It could also form the basis of future environmental product declarations.

\section{Functional unit}

The functional unit must represent the function of the options compared ${ }^{34}$. In the case of biosurfactants, it was decided to use $1 \mathrm{~kg}$ of product as a functional unit for 
environmental performance purposes and for expressing inputs, outputs and the environmental impact assessment. Similarly, for FAEE and MAG production it was decided to use as a functional unit $1 \mathrm{~kg}$ of produced FAEE and MAG, respectively. Due to lack of data on the industrial scale manufacture of biosurfactants and bioplasticizers, the operating parameters used for the evaluation of the processes were based on pilot plant results and prerequisites.

\section{System description}

The biotechnological products developed via the exploitation of waste oil and fats were developed in pilot scale, under the framework of the Bio-SURFEST project. The Life Cycle Analysis of the manufacturing stages for each of the products is described below.

\section{Sophorolipids production}

Based on the results from the pilot-scale production of sophorolipids, and the optimum operating conditions in which the highest yields of product recovery were achieved, the process is comprised of three stages. The first stage included the preparation of the pre-inoculum and its inoculation with the sophorolipids-producing yeast Candida bombicola. The pre-inoculum contained glucose, yeast extract and urea in order to accelerate yeast growth. During the second stage, an increase in the inoculum volume by extra addition of glucose and yeast extract, took place. The third stage was the main fermentation stage during which waste oil, glucose, yeast extract, potassium dihydrogen phosphate and magnesium sulfate heptahydrate were added. 
Fermentation was conducted under aerobic conditions, continuous agitation and controlled $\mathrm{pH}$ and temperature at 4.5 and $30^{\circ} \mathrm{C}$ respectively for 168 hours.

\section{Rhamnolipids production}

Rhamnolipids production took place in three distinct phases using the rhamnolipidproducing bacterium Pseudomonas aeruginosa. The first phase was the preparation of the pre-inoculum with the addition of peptone, sodium chloride, di-sodium hydrogen phosphate dodecahydrate and potassium dihydrogen phosphate. At the second phase, the pre-inoculum was transferred in a larger volume of buffered peptone water, in order to form the inoculum. The third phase was the main fermentation processing, where the inoculation to the fermentation vessel, containing the growth medium, was performed. The substrate comprised of waste oil, yeast extract, potassium dihydrogen phosphate, ammonium nitrate and magnesium sulfate heptahydrate. The operating conditions for rhamnolipids production by $P$. aeruginosa were aerobic, with continuous agitation and temperature controlled at $30^{\circ} \mathrm{C}$, while the whole cultivation period lasted 96 hours.

\section{Fatty Acid Ethyl Esters (FAEE) production}

The process of enzymatic ethanolysis, for the production of FAEE, consisted of three main phases and the formation of MAG, Triacylglycerol (TAG) and Diacylglycerols (DAG). The first phase was the preparation of raw materials with the specified physicochemical characteristics. The type of oil used in this case was waste oil mixture of animal and vegetable origin. In order to facilitate separation of the biocatalyst after 
reaction completion, and its subsequent reuse, the immobilized enzyme lipase (from Candida antarctica) on polyacrylate beads was utilized. The second phase was the main reaction in which the influent mixture of EtOH:oil, at the optimum ratio, was mixed under mesophilic temperature conditions, followed by the addition of the enzyme. The duration of the reaction phase maximizing FAEE yields was defined to be $8 \mathrm{~h}$. The third phase aimed at the product recovery in which FAEE recovery, biocatalyst regeneration and ethanol recovery took place. The product recovery phase was not part of this LCA survey.

\section{Monoacylglycerol (MAG) production}

With enzymatic glycerolysis MAG was produced either via reaction of fatty acids with glycerin, or through reaction of glycerin with triglycerides. The raw materials that were used for the glycerolysis process was industrial glycerol, sesame oil and the enzyme lipase, deriving from Candida Antarctica, immobilized on polyacrylate beads. During processing, the influent mixture reacted after the addition of catalyst. The reaction temperature was maintained at $40^{\circ} \mathrm{C}$ for $24 \mathrm{~h}$. In the last phase, the separation of the produced MAG took place via sedimentation and removal of excess glycerol. The biocatalyst could be regenerated and reused.

\section{System boundaries}

In this study, the gate-to-gate system boundaries were set to include only the manufacturing process of biosurfactants and bioplasticizers.

In the case of biosurfactants production, the system boundaries included the pre- 
inoculum and inoculum preparation as well as the biosurfactant (sophorolipids and rhamnolipids) production. Only the inputs (e.g. raw materials, energy) and outputs (e.g. emissions) associated with these processes were included within the boundaries. "Cradle" activities (e.g. oil production and purification, transport and storage) and "grave" activities (e.g. use and disposal phase) were not part of this study.

The system boundaries for bioplasticizers production were defined to include the raw materials preparation and mixing up to the reactions completion (FAEE and MAG production). The inputs used for the $\mathrm{LCl}$ database were the amounts of raw materials and the energy utilized, while the outputs included the emissions resulting from the processes. As in the case of biosurfactants production, the cradle and grave processes were not part of this study. Schematic diagrams of biosurfactants, FAEE and MAG production system boundaries are presented in Figure 1, 2 and 3.

\section{Key assumptions}

Some key assumptions were considered in order to conduct the environmental assessment.

Primary data on biosurfactants and bioplasticizers production were collected from the partners of Bio-SURFEST project, based on the optimum conditions of fermentation and enzymatic processes in pilot scale, since full-scale manufacturing is still under development. Certain elements such as solid wastes, wastewaters etc. were excluded from the study because it was not possible to define an appropriate pathway describing their further treatment or disposal with the current data.

Moreover, resource extraction and use and disposal activities were not included in 
the assessment. For all processes, the calculation of the energetic needs and electricity consumption was carried out with the hypothesis that all processes are taking place in Greece in 2013, where electricity is generated mainly from lignite, leading thus to high $\mathrm{CO}_{2}$ values.

\section{Inventory data sources}

Life Cycle Inventory data were determined for each of the products of this study and were obtained either directly from the partners of the Bio-SURFEST project, based on the optimum operating conditions of fermentation and enzymatic processes, or obtained from bibliographical sources.

The Ecoinvent v2.0 database, developed by the Swiss Centre of Life Cycle Inventories and available in SimaPro 7.3.3 software, was used to obtain data on the biogenic emissions of the processes and the electricity production by technology in Greece, based on annual averages. As it regards electricity production and distribution, the system did not take into account the energy transport and transformation, or distribution of energy losses. The energetic mixture considered for electricity production in Greece was lignite (54\%), oil (11\%) and natural gas (17\%), while only $18 \%$ was provided by renewables ${ }^{35}$. The life cycle inventory for each process is shown in detail in Table 1 and 2.

\section{Impact assessment}

Life Cycle Impact Assessment ( $\mathrm{LCIA})$ is the phase where the results of the inventory analysis are interpreted in terms of the impacts they have on the environment. The 
impact assessment of the biosurfactants and bioplasticizers production was based on the internationally accepted Environmental Product Declarations (EPD 2008 V1.03) developed in-line with the International Standard ISO 14025 (Type III Environmental Declarations), and thus the following impact categories were identified: Global Warming Potential (kg CO ${ }_{2}$ eq), Ozone Layer Depletion (kg CFC -11 eq), Photochemical Oxidation ( $\mathrm{kg} \mathrm{C}_{2} \mathrm{H}_{4} \mathrm{eq}$ ), Acidification Potential ( $\mathrm{kg} \mathrm{SO} \mathrm{S}_{2}$ eq), Eutrophication ( $\mathrm{kg} \mathrm{PO} \mathrm{P}_{4} \mathrm{eq}$ ) and non-renewable fossil (MJ eq).

\section{RESULTS AND DISCUSSION}

According to the goals of this study, the most pollutant stages during processing of waste oils and fats via the proposed biotechnological processes were identified. Moreover, the overall environmental performance of each process per $\mathrm{kg}$ of product produced was quantified per impact category.

\section{Overview of results of the fermentation processes for sophorolipids and rhamnolipids production}

In Table 3 and 4 the LCIA results of the fermentation processes for the production of sophorolipid and rhamnolipid biosurfactants, expressed per $\mathrm{kg}$ of product produced, are presented. The results indicate that the main environmental impact is due to the fermentation process, mainly because it is more energy intensive, compared to the phases of pre-inoculum and inoculum preparation for both processes. The main inputs for the calculation of the LCIA are the electricity consumption and the biogenic emissions $\left(\mathrm{CO}_{2}\right)$ generated by the metabolic activity of the strains. This makes the 
fermentation process present an unacceptable environmental compatibility in the assessed boundaries.

Between the two processes, the rhamnolipid production process seems to have better environmental performance than sophorolipids production. Specifically regarding the global warming potential of 100 years, which is a key indicator in LCA studies and quantifies the amount of energy the emissions of 1 ton of a gas will absorb over 100 years, relative to the emissions of 1 ton of $\mathrm{CO}_{2}$, the relative emissions in the rhamnolipid production case reach the value of $567.49 \mathrm{~kg} \mathrm{CO}_{2}$ eq. compared to sophorolipid production value of $734.68 \mathrm{~kg} \mathrm{CO}_{2}$ eq. This is attributed mainly due to the difference in the time required for their production during fermentation. In particular, the sophorolipids production is a longer process than rhamnolipids and, as a result, is more energy intensive because it requires higher amount of thermal energy in order to maintain the culture medium in steady temperature conditions.

This result is in agreement with a recent study, where a cradle-to-gate approach was developed to assess environmental impacts associated with the fermentation and purification process of acetylated acidic sophorolipid biosurfactants ${ }^{29}$. Authors concluded that the production phase, including sophorolipids and dispenser production, is mostly responsible for the impact of every category. In addition, around $90 \%$ of the impact during the production phase was attributed to fermentation, especially due to the use of rapeseed oil (47\%) and glucose (41\%), with only $7 \%$ deriving from electricity. Large consumption of water for the production of rapeseed oil and glucose leads to most of the damage to ecosystems while most of the impact regarding resource use is caused by glucose and energy production. 
Until today the number of LCA studies performed for the production of surfactants is limited, while LCA assessments are mainly focused on their application as detergents and cleaning products ${ }^{36-40}$. Although there is still not a widely accepted definition for 'green surfactants', or else 'biosurfactants', for practical reasons, most of the times, biosurfactants are described as substances of biological origin ${ }^{41}$. For example, in their study Guilbot et al. ${ }^{37}$ explored the case of an alkyl polyglucoside (APG), composed of cetearyl glucoside and cetearyl alcohol deriving from palm kernel oil. This surfactant, used as a self-emulsifier in cosmetics, is considered 'green' because of its vegetable origin and also due to its manufacturing process complying with the 12 rules of Green Chemistry ${ }^{37,42}$. Although this study does not assess the production of microbial biosurfactants, valuable information on process hotspots may be obtained out of it that should be taken into account when assessing an LCA study on microbial biosurfactants. As it regards microbial biosurfactants, only one study, as mentioned above, has been published recently describing a cradle-to-grave approach for acetylated acidic sophorolipids where it was concluded that their environmental impact was similar to the one of chemical surfactants deriving from fossil resources ${ }^{29}$. Therefore, the importance of a life cycle based method for sustainability assessment and development is highlighted ${ }^{43}$.

\section{Overview of results of the enzymatic processes}

The LCIA results of the enzymatic processes for the production of MAG and FAEE, expressed per kg of product produced in each process, are presented in Table 5.

Products' handling beyond the factory gate, is out of the system boundaries and on the 
contrary with the biosurfactants production, in which the biogenic emissions are taken into account in the LCI formation, the physicochemical production of MAG and FAEE has no biogenic emissions which could be taken into account. As a result, the main environmental impact in glycerolysis and ethanolysis in this gate-to-gate analysis, is due to the energy requirements of the processes. As presented in Table 5, the GWP100 of MAG production has been estimated as $180.75 \mathrm{~kg} \mathrm{CO}_{2}$ eq., which is almost threefold higher compared to the emissions arising by the FAEE manufacturing $(59.59 \mathrm{~kg} \mathrm{CO} 2$ eq.).

The FAEE production stage takes place at $35^{\circ} \mathrm{C}$ for $8 \mathrm{~h}$ and thus, temperature has to be maintained stable for the whole reaction cycle. As a result, energy intensive equipment is needed for the temperature control of the process. Similarly, during MAG production the temperature has to be maintained at $40^{\circ} \mathrm{C}$ for $24 \mathrm{~h}$, and as result the process has higher environmental impact than FAEE production. Consequently, the thermal needs of the process have the main effect on the overall process. Additionally, the use of sesame oil in MAG manufacturing has negative effect on the overall environmental process performance since it is a process competing with the food chain. As a result of the selected system boundaries, this parameter was not assessed. On the contrary, the reuse of waste oil mixtures for the production of FAEE will have possibly positive environmental effects, but also in this case the upstream processes, such as production of waste oil, was out of the present systems' boundaries.

Similar to results obtained from the fermentation processes, for rhamnolipids and sophorolipids production, the main hotspot identified in these enzymatic processes is the consumption of energy. The presented LCA was conducted considering the specific 
electricity mix used in Greece. However, the electricity mix varies from one country to another. Improvements in energy efficiency, attributed to renewable energy sources such as solar photovoltaic panels, wind and nuclear power are expected to promote decarbonisation of the electricity mix due to the decrease in the share of lignite and hard coal $^{44}$.

Currently bioplasticizers, alternative to conventional phthalate ones, have been studied regarding their impact on the environment using the LCA approach. In particular, SOFT-N-SAFE LIQ, an acetic acid ester of monoglycerides made from fully regenerated castor oil, was shown to have a lower environmental impact in terms of greenhouse gas emissions, non-renewable resource depletion and water resources 30,45. Life cycle analysis is currently in progress for another biobased plasticizer, POLYSORB $^{\circledR}$ ID37, which is composed of isosorbide diesters produced of vegetable origin fatty acids and isosorbide obtained by simple modification of sorbitol ${ }^{31}$. Citroflex A-4, or else citric acid ester acetyltri-n-butyl citrate, is a widely used plasticizer and lubricant in food contact polymer applications ${ }^{46}$. It performs better over dibutyl phthalate in cellulose nitrate films and presents outstanding properties as a plasticizer in vinyl toys while it is characterized by excellent processing options, low toxicity, improved adherence to metals, low volatility and resistance to yellowing ${ }^{47}$. Till today, however, no LCA study has been reported for its production.

From the above it is clear that bioplasticizers produced from biobased raw materials are an upcoming field of study. Due to their biodegradable nature, low toxicity, low volatility, low migration and high heat stability are expected to outcompete phthalate plasticizers as an eco-sustainable solution. However, LCA studies regarding their 
production are still very limited but of crucial importance in order to identify hotspots and potential bottlenecks that will help design and develop greener processes with societal and environmental benefits.

\section{CONCLUSIONS}

The study revealed that air emissions, electricity and thermal requirements, during their production, are the key contributors to the potential environmental impacts identified in this LCIA. Among the biosurfactant production processes, the sophorolipids production resulted to $22.7 \%$ higher environmental impact compared to the rhamnolipids production. Similarly, FAEE production can be classified as a more environmental friendly process compared to MAG production, resulting to $67 \%$ lower environmental impact based on the environmental indicators assessed. Environmental impacts due to energy consumption from all processes studied could be mitigated with the use of renewable energy sources to decrase the environmatal footprint. Further analysis on their environmental performance and potential future work could extend the present study to include the entire cradle-to-grave analysis based on data derived from a full-scale production plant.

\section{ACKNOWLEDGEMENTS}

The authors would like to thank the Bio-SURFEST project's consortium for providing all the necessary information that consisted the basis for the conducted LCA studies. This work was supported by the European Commission and programme FP7 - SME $2011-286834$ 'Development of novel environmentally added-value surfactants and 
esters by biotechnological processes from fats and oils waste streams (Bio-SURFEST)'.

Dr. Constantina Kourmentza also acknowledges the financial support provided through

the funding scheme FP7-PEOPLE-2013-IEF-Marie Curie Action: Intra-European

Fellowships for Career Development (grant no. 625774). 


\section{REFERENCES}

1. Lin CSK, Pfaltzgraff LA, Herrero-Davila L, Mubofu EB, Abderrahim S, Clark JH, et al. Food waste as a valuable resource for the production of chemicals, materials and fuels. Current situation and global perspective. Energy Environ Sci [Internet]. 2013;6(2):426-64. Available from: http://dx.doi.org/10.1039/C2EE23440H

2. European Commission. On the management of bio-waste in the European Union. Comm Eur Communities [Internet]. 2008;COM(2008):18. Available from: http://ec.europa.eu/environment/waste/compost/pdf/green_paper_en.pdf

3. European Commission. Innovating for Sustainable Growth: A Bioeconomy for Europe [Internet]. Brussels; 2012. Available from:

http://ec.europa.eu/research/bioeconomy/pdf/official-strategy_en.pdf

4. Anankanbil S, Suo F, Jensen PR, Guo Z. Lipid Biotechnology and Biochemistry. In: Akoh CC, editor. Food Lipids: Chemistry, Nutrition and Biotechnology. Fourth Edi. Taylor \& Francis; 2017. p. 782-809.

5. Kourmentza C, Freitas F, Alves V, Reis MAM. Microbial Conversion of Waste and Surplus Materials into High- Value Added Products: The Case of Biosurfactants. In: Kalia VC, Kumar P, editors. Microbial Appications Vol1 - Bioremediation and Bioenergy [Internet]. Springer International Publishing; 2017. p. 29-78. Available from: http://link.springer.com/10.1007/978-3-319-52669-0

6. Kosaric N, Vardar-Sukan F. Biosurfactants Production and Utilization-Processes, Technologies, and Economics. In: Kosaric N, Vardar-Sukan F, editors. Surfactant Science Series volume 159 [Internet]. 1st ed. Boca Raton, FL: CRC Press, Taylor \& Francis Group; 2015. p. 389. Available from: 
https://www.crcpress.com/Biosurfactants-Production-and-UtilizationProcessesTechnologies-and/Kosaric-Sukan/p/book/9781466596696

7. Thavasi R, Subramanyam Nambaru VRM, Jayalakshmi S, Balasubramanian T, Banat IM. Biosurfactant Production by Azotobacter chroococcum Isolated from the Marine Environment. Mar Biotechnol [Internet]. 2009;11(5):551-6. Available from: http://dx.doi.org/10.1007/s10126-008-9162-1

8. Smyth TJP, Perfumo A, McClean S, Marchant R, Banat IM. Handbook of Hydrocarbon and Lipid Microbiology. Handb Hydrocarb Lipid Microbiol [Internet]. 2010;1(lii):1-6. Available from: http://www.springerlink.com/index/10.1007/978-3-540-77587-4

9. Nitschke M, Pastore GM. Biosurfactant production by Bacillus subtilis using cassava-processing effluent. Appl Biochem Biotechnol [Internet]. 2004;112(3):163-72. Available from: http://dx.doi.org/10.1385/ABAB:112:3:163

10. Gudiña EJ, Teixeira JA, Rodrigues LR. Biosurfactants produced by marine microorganisms with therapeutic applications. Mar Drugs. 2016;14(2).

11. Desai JD, Banat IM. Microbial production of surfactants and their commercial potential. Microbiol Mol Biol Rev. 1997 Mar;61(1):47-64.

12. Nitschke M, Costa SGVAO. Biosurfactants in food industry. Trends Food Sci Technol. 2007;18(5):252-9.

13. Inès $\mathrm{M}$, Dhouha G. Glycolipids biosurfactants; potential related biomedical and biotechnological applications. Carbohydr Res [Internet]. 2015 Jul [cited 2015 Aug 7];416:59-69. Available from:

http://www.sciencedirect.com/science/article/pii/S0008621515002207 
14. Perfumo A, Rudden M, Smyth TJP, Marchant R, Stevenson PS, Parry NJ, et al. Rhamnolipids are conserved biosurfactants molecules: Implications for their biotechnological potential. Appl Microbiol Biotechnol. 2013;97(16):7297-306.

15. Research and Markets. Global Biosurfactants Market - Segmented by Product Type and Geography - Trends and Forecasts (2016 - 2021) [Internet]. 2016. Available from: http://www.researchandmarkets.com/research/f6clwc/global

16. Vieira MGA, da Silva MA, dos Santos LO, Beppu MM. Natural-based plasticizers and biopolymer films: A review. Eur Polym J [Internet]. 2011 [cited 2017 Apr 25];47(3):254-63. Available from: http://www.sciencedirect.com/science/article/pii/S0014305710004763

17. Mekonnen T, Mussone $\mathrm{P}$, Khalil H, Bressler D. Progress in bio-based plastics and plasticizing modifications. J Mater Chem A [Internet]. 2013;1(43):13379-98. Available from: http://dx.doi.org/10.1039/C3TA12555F

18. Baltacioğlu H, Balköse D. Effect of zinc stearate and/or epoxidized soybean oil on gelation and thermal stability of PVC-DOP plastigels. J Appl Polym Sci [Internet]. 1999;74(10):2488-98. Available from: http://dx.doi.org/10.1002/(SICI)10974628(19991205)74:10\%3C2488::AID-APP18\%3E3.0.CO

19. Markets and Markets. Bio Plasticizer Market by type ( ESBO, Citrates, Castor oil , succinic acid \& others ), by application ( packaging materials , medical devices , consumer goods, wires \& cables, building \& construction \& others ), by region Trends \& forecasts to 2020 [Internet]. 2015. Available from: http://www.marketsandmarkets.com/PressReleases/bioplasticizers.asp 20. Berger M, Schnelder MP. Enzymatic esterification of glycerol II. Lipase-catalyzed 
synthesis of regioisomerically pure 1(3)-rac-monoacylglycerols. J Am Oil Chem Soc [Internet]. 1992;69(10):961-5. Available from:

http://dx.doi.org/10.1007/BF02541058

21. Xiao C, Zhang Z, Zhang J, Lu Y, Zhang L. Properties of regenerated cellulose films plasticized with $\alpha$-monoglycerides. J Appl Polym Sci [Internet].

2003;89(13):3500-5. Available from: http://dx.doi.org/10.1002/app.12509

22. Muniyappa PR, Brammer SC, Noureddini H. Improved conversion of plant oils and animal fats into biodiesel and co-product. Bioresour Technol. 1996;56(1):19-24.

23. Jamlus NNA, Derawi D, Salimon J. Production of MAG via enzymatic glycerolysis. AIP Conf Proc [Internet]. 2015;1678:50034. Available from: http://scitation.aip.org/content/aip/proceeding/aipcp/10.1063/1.4931313

24. Kapoor M, Gupta MN. Obtaining monoglycerides by esterification of glycerol with palmitic acid using some high activity preparations of Candida antarctica lipase B. Process Biochem [Internet]. 2012;47(3):503-8. Available from: http://dx.doi.org/10.1016/j.procbio.2011.12.009

25. Gan LH, Ooi KS, Goh SH, Gan LM, Leong YC. Epoxidized esters of palm olein as plasticizers for poly(vinyl chloride). Eur Polym J. 1995;31(8):719-24.

26. Kandula S, Stolp L, Grass M, Woldt B, Kodali D. Functionalization of soy fatty acid alkyl esters as bioplasticizers. J Vinyl Addit Technol [Internet]. 2017;23:93-105. Available from: http://doi.wiley.com/10.1002/vnl.21486

27. Lima LP, Santos FFP, Costa E, Fernandes FAN. Production of free fatty acids from waste oil by application of ultrasound. Biomass Convers Biorefinery [Internet]. 
2012;2(4):309-15. Available from: http://dx.doi.org/10.1007/s13399-012-0056-

0

28. Yates MR, Barlow CY. Life cycle assessments of biodegradable, commercial biopolymers - A critical review. Resour Conserv Recycl [Internet]. 2013;78:5466. Available from: http://dx.doi.org/10.1016/j.resconrec.2013.06.010

29. Baccile N, Babonneau F, Banat IM, Ciesielska K, Cuvier A-S, Devreese B, et al. Development of a Cradle-to-Grave Approach for Acetylated Acidic Sophorolipid Biosurfactants. ACS Sustain Chem Eng [Internet]. 2017;5:1186-98. Available from: http://pubs.acs.org/doi/abs/10.1021/acssuschemeng.6b02570

30. Danisco A/S. Danisco publishes environmental impact assessment for bio-based plasticizer. Addit Polym [Internet]. 2012;2012(3):11. Available from:

http://linkinghub.elsevier.com/retrieve/pii/S0306374712700489

31. Roquette. POLYSORB ${ }^{\circledR}$ ID 37: a 100\% biobased plasticizer [Internet]. 2014. Available from: http://polymeradditives.specialchem.com/storefronts/roquette/pvc-plasticizer

32. Bare JC, Hofstetter P, Pennington DW, Udo de Haes HA, Midpoints versus Endpoints: The Sacrifices and Benefits. Int J Life Cycle Assess. 2000;5(6):319326. Available from: http://dx.doi.org/ 10.1007/BF02978665

33. Jiménez-González C, Kim S, Overcash MR. Methodology for developing gate-togate Life cycle inventory information. Int J Life Cycle Assess [Internet]. 2000;5(3):153-9. Available from: http://dx.doi.org/10.1007/BF02978615

34. Leceta I, Etxabide A, Cabezudo S, De La Caba K, Guerrero P. Bio-based films prepared with by-products and wastes: Environmental assessment. J Clean Prod 
[Internet]. 2014;64:218-27. Available from:

http://dx.doi.org/10.1016/j.jclepro.2013.07.054

35. Chatzisymeon E, Foteinis S, Mantzavinos D, Tsoutsos T. Life cycle assessment of advanced oxidation processes for olive mill wastewater treatment. J Clean Prod [Internet]. 2013;54:229-34. Available from:

http://dx.doi.org/10.1016/j.jclepro.2013.05.013

36. Saouter E, van Hoof G. LCA Case Studies A Database for the Life-Cycle Assessment of Procter \& Gamble Laundry Detergents. Int J Life Cycle Assess. 2002;7(2):103-14.

37. Guilbot J, Kerverdo S, Milius A, Escola R, Pomrehn F. Life cycle assessment of surfactants: the case of an alkyl polyglucoside used as a self emulsifier in cosmetics. Green Chem. 2013;15(12):3337-54.

38. Fogliatti DP, Kemppainen SA, Kalnes TN, Fan J, Shonnard DR. Life Cycle Carbon Footprint of Linear Alkylbenzenesulfonate from Coconut Oil, Palm Kernel Oil, and Petroleum-Based Paraffins. ACS Sustain Chem Eng [Internet].

2014;2(7):1828-34. Available from: http://dx.doi.org/10.1021/sc5001622

39. Pittinger CA, Sellers JS, Janzen DC, Koch DG, Rothgeb TM, Hunnicutt ML. Environmental life-cycle inventory of detergent-grade surfactant sourcing and production. J Am Oil Chem Soc. 1993;70(1):1-15.

40. Golsteijn L, Menkveld R, King H, Schneider C, Schowanek D, Nissen S. A compilation of life cycle studies for six household detergent product categories in Europe: the basis for product-specific A.I.S.E. Charter Advanced Sustainability Profiles. Environ Sci Eur [Internet]. 2015;27(1):23. Available from: 
http://www.enveurope.com/content/27/1/23

41. Somasundaran P, Patra P, Albino J, Nambi I. Microbially Derived Biosurfactants. In: Surfactant Science and Technology [Internet]. CRC Press; 2014. p. 333-44. Available from: https://doi.org/10.1201/b16802-17

42. Anastas P, Eghbali N. Green Chemistry: Principles and Practice. Chem Soc Rev [Internet]. 2010;39(1):301-12. Available from:

http://xlink.rsc.org/?DOI=B918763B

43. Klöpffer W. Life cycle assessment as part of sustainability assessment for chemicals. Environ Sci Pollut Res. 2005;12(January 2004):173-7.

44. Gallego-schmid A, Mendoza JMF, Jeswani HK, Azapagic A. Life cycle environmental impacts of vacuum cleaners and the effects of European regulation. Sci Total Environ [Internet]. 2016;559:192-203. Available from: http://dx.doi.org/10.1016/j.scitotenv.2016.03.149

45. Danisco A/S. Grindsted ${ }^{\circledR}$ Soft-N-Safe The safe and sustainable plasticizer for PVC [Internet]. 2009. p. 8. Available from: http://www.daniscosoftnsafe.com/fileadmin/user_upload/softnsafe/documents/Brochures/brochur e-softnsafe.pdf

46. Vertellus Specialties Inc. Citroflex ${ }^{\circledR}$ Citric Acid Esters [Internet]. 2014. p. 16. Available from: http://www.chempoint.com/products/catalog/vertellusspecialties/citroflex-citric-acid-esters/citroflex ${ }^{\circledR}$-citric-acid-esters

47. Vertellus. CITROFLEX A-4 Safety Data Sheet [Internet]. 2014. p. 1-7. Available from: http://www.vertellus.com/Documents/msds/Citroflex ${ }^{\circledR}$ A-4 English.pdf 


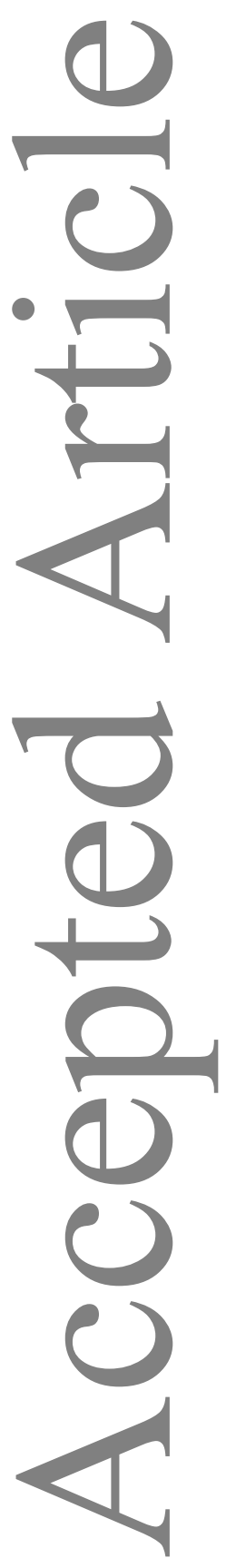

This article is protected by copyright. All rights reserved. 


\section{FIGURE AND TABLE CAPTIONS}

Figure 1. System boundaries for sophorolipids and rhamnolipids production

Figure 2. System boundaries for FAEE production

Figure 3. System boundaries for MAG production

Table 1. Life Cycle Inventory values per kg of sophorolipids and rhamnolipids produced at optimal operating conditions.

Table 2. Life Cycle Inventory, values per kg of FAEE and MAG produced at optimal operating conditions.

Table 3. LCIA results per kg of sophorolipids produced in Gate-to-Gate approach

Table 4. LCIA results per kg of rhamnolipids produced in Gate-to-Gate approach.

Table 5. LCIA results per kg of MAG and FAEE produced in Gate-to-Gate approach. 
TABLE 1

\begin{tabular}{|c|c|c|c|c|}
\hline Raw Materials & $\begin{array}{l}\text { Pre- } \\
\text { Inoculum }\end{array}$ & Inoculum & Fermentation & Product \\
\hline Glucose (kg) & 0.091 & 0.091 & 5.055 & \multirow{8}{*}{$\begin{array}{l}\text { ñ } \\
\frac{0}{2} \\
\frac{0}{2} \\
\frac{0}{0} \\
\frac{0}{2} \\
\frac{2}{n}\end{array}$} \\
\hline Urea (kg) & 0.00091 & & 0.364 & \\
\hline Yeast extract (kg) & 0.0091 & 0.0182 & 0.455 & \\
\hline Water (L) & 0.91 & 9.1 & 91 & \\
\hline Waste oil (kg) & & & 0.6825 & \\
\hline Potassium dihydrogen phosphate (kg) & & & 0.091 & \\
\hline Magnesium sulfate heptahydrate (kg) & & & 0.0455 & \\
\hline Energy consumption (kWh) & 39.76 & 122.86 & 433.25 & \\
\hline Peptone (kg) & 12.5 & 125 & & \multirow{14}{*}{$\begin{array}{l}20 \\
\frac{2}{2} \\
\frac{1}{3} \\
\frac{0}{2} \\
\frac{0}{0} \\
\frac{2}{n}\end{array}$} \\
\hline Di-pottasium hydrogen phosphate (kg) & & & 0.0625 & \\
\hline Pottasium dihydrogen phosphate $(\mathrm{kg})$ & 1.875 & & 0.0625 & \\
\hline Yeast extract $(\mathrm{kg})$ & & & 0.625 & \\
\hline Water (L) & 1.25 & 12.5 & 125 & \\
\hline Glucose (kg) & & & 0.625 & \\
\hline Sodium chloride $(\mathrm{kg})$ & 6.25 & & & \\
\hline Waste oil (kg) & & & 5 & \\
\hline Disodium phosphate dodecahydrate $(\mathrm{kg})$ & 11.25 & & & \\
\hline Ammonium nitrate $(\mathrm{kg})$ & & & 0.0625 & \\
\hline Copper(II) sulfate anhydride (kg) & & & 0.00025 & \\
\hline Magnesium sulfate heptahydrate $(\mathrm{kg})$ & & & 0.001 & \\
\hline Manganese (II) sulphate 1-hydrate (kg) & & & 0.00025 & \\
\hline Energy consuption (kWh) & 39.76 & 98.38 & 248.57 & \\
\hline
\end{tabular}


TABLE 2

\begin{tabular}{lcc}
\hline Raw Materials & Reaction phase & Product \\
\hline Waste oil (kg) & 0.82 & \\
Ethanol (kg) & 0.18 & 而 \\
Enzymes (kg) & 0.041 & \\
Energy consuption (kWh) & 60.6 & \\
\hline Sesame oil (kg) & 2.1 & 3 \\
Glycerol (kg) & 0.4 & ด \\
Water (L) & 0.017 & \\
Enzymes (kg) & 0.105 & \\
Energy consuption (kWh) & 182 & \\
\hline
\end{tabular}


TABLE 3

\begin{tabular}{llllll}
\hline Impact category & Unit & Total & Pre-inoculum & Inoculum & Fermentation \\
\hline Global warming (GWP100) & $\mathrm{kg} \mathrm{CO}_{2}$ eq & 734.6848584 & 39.48722555 & 129.1081318 & 566.0895011 \\
Ozone layer depletion (ODP) & $\mathrm{kg} \mathrm{CFC-11} \mathrm{eq}$ & $2.61815 \mathrm{E}-05$ & $1.40718 \mathrm{E}-06$ & $4.60094 \mathrm{E}-06$ & $2.01734 \mathrm{E}-05$ \\
Photochemical oxidation & $\mathrm{kg} \mathrm{C}_{2} \mathrm{H}_{4}$ eq & 0.223587104 & 0.012017172 & 0.039291559 & 0.172278373 \\
Acidification & $\mathrm{kg} \mathrm{SO}_{2}$ eq & 3.799283957 & 0.204200727 & 0.667658314 & 2.927424915 \\
Eutrophication & $\mathrm{kg} \mathrm{PO}_{4}^{-3}-$ eq & 0.149048208 & 0.008010918 & 0.02619264 & 0.114844651 \\
Non renewable, fossil & $\mathrm{MJ} \mathrm{eq}$ & 11390.8092 & 612.2236585 & 2001.737314 & 8776.848223 \\
\hline
\end{tabular}


TABLE 5

\begin{tabular}{llll}
\hline Impact category & Unit & $\begin{array}{l}\text { Total Impact for } \\
\text { FAEE production }\end{array}$ & $\begin{array}{l}\text { Total Impact for } \\
\text { MAG production }\end{array}$ \\
\hline Global warming (GWP100) & $\mathrm{kg} \mathrm{CO}_{2}$ eq & 59.58836994 & 180.7514 \\
Ozone layer depletion (ODP) & $\mathrm{kg} \mathrm{CFC}-11 \mathrm{eq}$ & $2.12351 \mathrm{E}-06$ & $6.44 \mathrm{E}-06$ \\
Photochemical oxidation & $\mathrm{kg} \mathrm{C}_{2} \mathrm{H}_{4}$ eq & 0.018134567 & 0.055008 \\
Acidification & $\mathrm{kg} \mathrm{SO}_{2}$ eq & 0.308149996 & 0.934722 \\
Eutrophication & $\mathrm{kg} \mathrm{PO}_{4}^{-3}$ - eq & 0.012088911 & 0.03667 \\
Non renewable, fossil & $\mathrm{MJ} \mathrm{eq}$ & 923.8788293 & 2802.432 \\
\hline
\end{tabular}




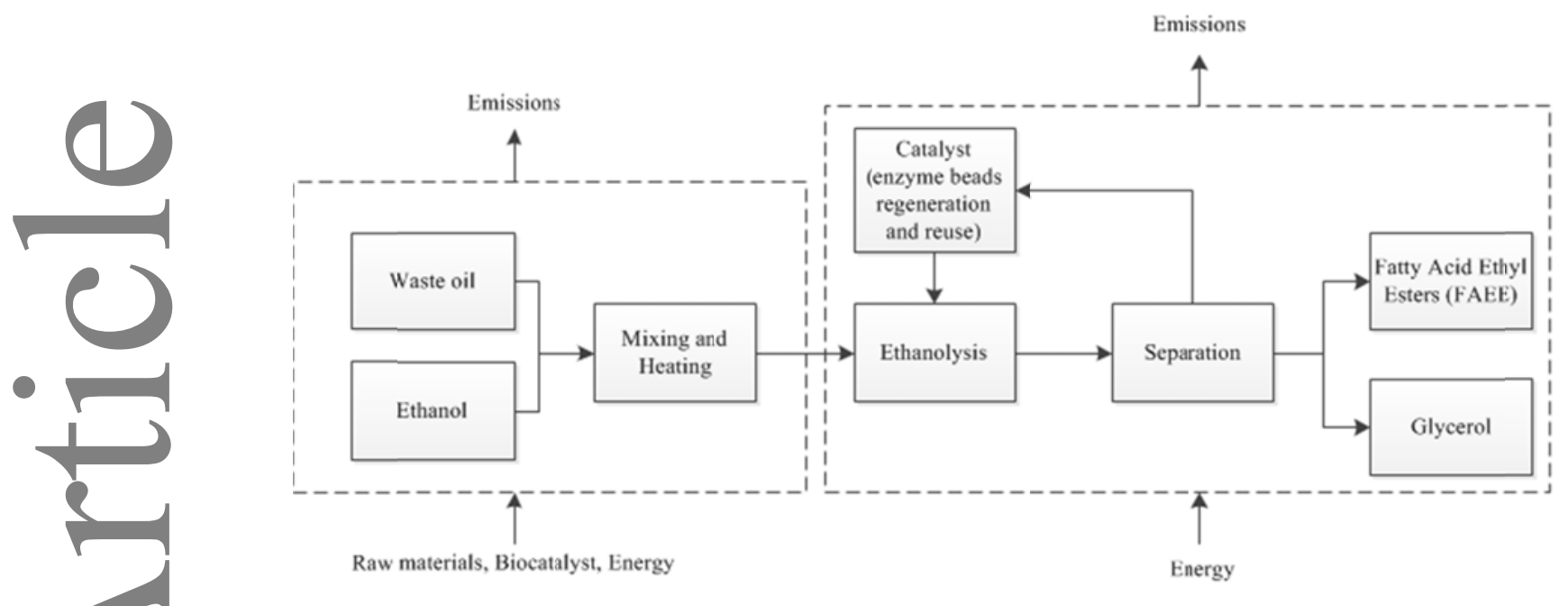

FIG. 2 


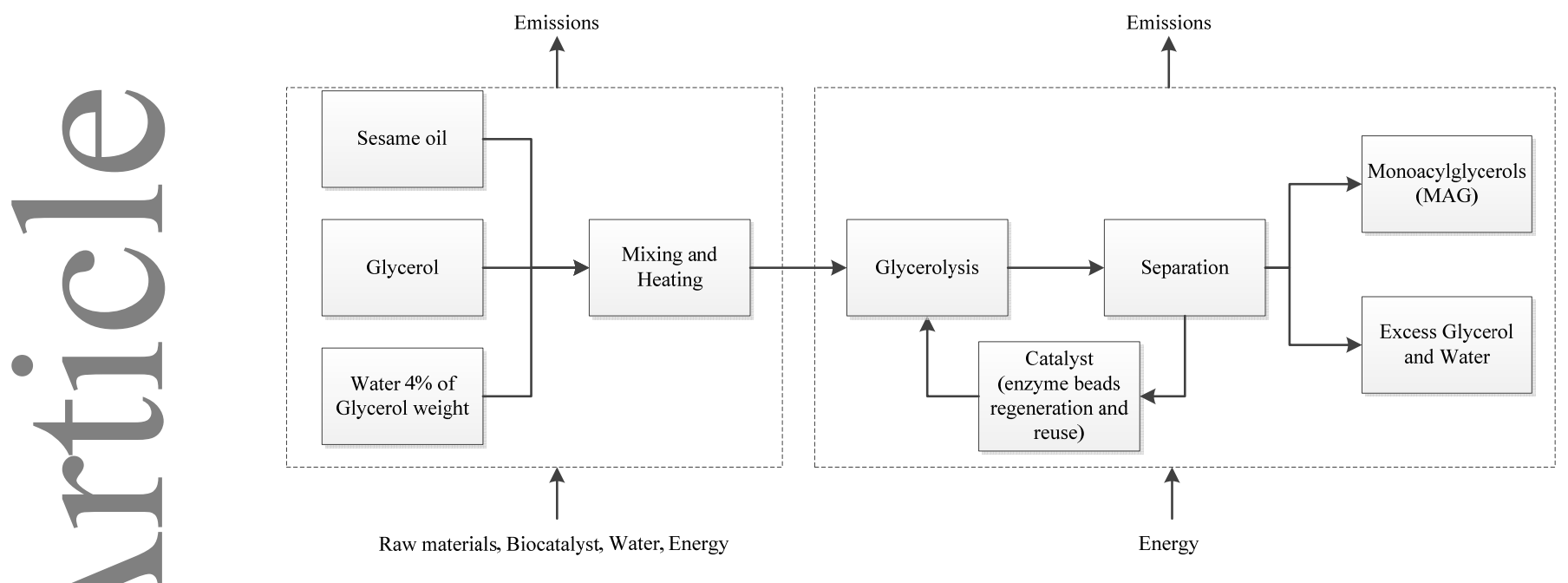

FIG. 3

This article is protected by copyright. All rights reserved. 